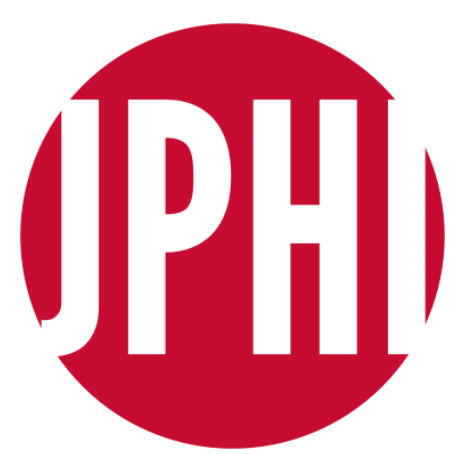

Jurnal Penegakan Hukum Indonesia (JPHI)

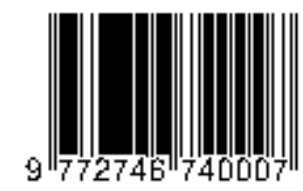

E-ISSN: 2746-7406

\section{PERKAWINAN ADAT SUKU DAYAK MERATUS DI KALIMANTAN SELATAN}

\author{
${ }^{1}$ Fathul Achmadi Abby; ${ }^{2}$ Ifrani*; ${ }^{3}$ Muhammad Topan
}

Fakultas Hukum, Universitas Lambung Mangkurat. Jl.Brigjen Hasan Basry, Kota Banjarmasin 70123

${ }^{1}$ Email: abby57bjb@gmail.com

${ }^{2}$ Email: ifrani@ulm.ac.id

Scopus ID: 57209340626

3 Email: muhammadtopan@gmail.com

\begin{tabular}{|c|c|c|}
\hline \multicolumn{2}{|c|}{$\begin{array}{ll}\text { Submitted } & : 20 / 01 / 2021 \\
\text { Revised } & : 25 / 01 / 2021 \\
\text { Accepted } & : 28 / 01 / 2021 \\
\text { Published } & : 28 / 01 / 2021\end{array}$} & Abstract \\
\hline $\begin{array}{l}\text { Editorial C } \\
\text { Jl. Brigjen } \\
\text { Komplek Pc } \\
\text { Utara Jalur } \\
\text { Banjarmasi } \\
\text { Kalimantan } \\
\text { Indonesia }\end{array}$ & $\begin{array}{l}: \text { 25/01/2021 } \\
: \text { 28/01/2021 } \\
: \text { 28/01/2021 } \\
\text { ce: } \\
\text { lasan Basri } \\
\text { k Banjarmasin } \\
\text { No. } 9 \text { Kota } \\
\text { rovinsi } \\
\text { latan; Republik } \\
\text { 25). }\end{array}$ & $\begin{array}{l}\text { This research is aim to study, the customary marriage law of } \\
\text { indigenous people of the Dayak Kotabaru Regency, South Kalimantan. } \\
\text { Second, the marriage law based on the Dayak Customs of the } \\
\text { Kotabaru Regency of South Kalimantan compared to studies and } \\
\text { teachings of the Customary Law? The research method used in this } \\
\text { study is the socio-legal legal research. The research is not only } \\
\text { limited to examining the law as a series of norms or statutory rules } \\
\text { related to customary law of Dayak, but also examining the living law. } \\
\text { Such legal research can also be called a sociological juridical research } \\
\text { method. The results of the research show that first, there are two } \\
\text { concepts of marriage relations in the Dayak customary tribe, first } \\
\text { there is marriage based on the sacred bond of marriage (legal } \\
\text { marriage) and secondly is 'palas', which is a relationship that appears } \\
\text { without a legal marriage bond and can even be considered adultery. } \\
\text { Second, the legal norms of Dayak customary marriage are based on } \\
\text { the principles of customary law, namely the principle of harmony, the } \\
\text { principle of decency and the principle of linearity. } \\
\text { Keywords: Marriage, Adat, Dayak. }\end{array}$ \\
\hline \multicolumn{2}{|c|}{$\begin{array}{l}\text { Principal Contact } \\
+6282157709493\end{array}$} & Abstrak \\
\hline \multicolumn{2}{|c|}{$\begin{array}{l}\text { @ JPHI } 2020 \\
\text { Licensed under the CC } 4.0 . \\
\text { Creative Commons } \\
\text { Attribution-ShareAlike } 4.0 \\
\text { International License }\end{array}$} & $\begin{array}{l}\text { Penelitian kali ini dimaksudkan untuk menjawab } 2 \text { (dua) } \\
\text { permasalahan pokok, yaitu; Pertama, Bagaimana hukum perkawinan } \\
\text { adat pada Masyarakat adat dayak Kabupaten Kotabaru Kalimantan } \\
\text { Selatan ? Kedua, Bagaimana hukum perkawinan berdasarkan adat } \\
\text { Dayak Kabupaten Kotabaru Kalimantan Selatan ditinjau menurut } \\
\text { kajian dan ajaran Asas dan Ilmu Hukum Adat? Metode penelitian } \\
\text { yang digunakan adalah metode penelitian hukum socio-legal. } \\
\text { Penggunaan metode penelitian yang demikian tidak hanya sebatas } \\
\text { menelaah hukum sebagai sederetan norma-norma atau kaidah-kaidah } \\
\text { perundang-undangan yang berhubungan dengan perkawinan adat }\end{array}$ \\
\hline
\end{tabular}


dayak, tetapi juga menelaah bagaimana agar hukum itu hidup dalam kehidupan masyarakat. Penelitian hukum yang demikian, dapat pula disebut sebagai metode penelitian yuridis sosiologis. Hasil dari penelitian didapatkan bahwa pertama, ada dua konsep hubungan perkawinan dalam suku adat Dayak, pertama ada perkawinan berdasarkan ikatan suci pernikahan (perkawinan secara sah) dan kedua adalah 'palas' yakni hubungan yang muncul tanpa adanya ikatan pernikahan yang sah dan bahkan bisa dianggap sebagai zinah. Kedua, norma-norma hukum perkawinan adat Dayak dilandasi pada asas-asas hukum adat yakni asas kerukunan, asas kepatutan dan asas laras.

Kata Kunci: Perkawinan, Adat, Dayak.

\section{PENDAHULUAN}

Perkawinan bagi setiap orang merupakan hal penting, sehingga peraturan itu diatur pada norma hukum. Dapat kita lihat dalam Pasal 28B Ayat (1) Undang-undang Dasar 1945 mengatur bahwa "setiap orang berhak membentuk keluarga dan melanjutkan keturunan melalui perkawinan yang sah". Dan dalam Undang Undang Republik Indonesia Nomor 1 Tahun 1974 tentang Perkawinan Pasal 2 Ayat (1 \& 2) ini menyebutkan bahwa perkawinan itu sah apabila dilaksanakan menurut hukum masing-masing agamanya dan kepercayaan, serta dicatat menurut peraturan perundang-undangan yang berlaku. Dimana Undang Undang telah menentukan batas usia bagi pria maupun wanita untuk melangsungkan perkawinan, yaitu pada umur 19 (sembilan belas) tahun untuk pria dan umur 16 (enam belas) tahun bagi wanita.

Perkawinan di Indonesia ternyata tidak lepas dari perkawinan adat, dimana hukum perkawinan adat juga berlaku pada lingkungan masyarakat pada umumnya yang tinggal dan hidup di pedesaan. Hal ini ditunjukkan berbagai macam upacara perkawinan adat, mulai dari pakaian mempelai yang beraneka ragam menunjukkan latar belakang dari Hukum Perkawinan Adat di kalangan masyarakat Indonesia, salah satunya Suku Dayak yang berada di Kabupaten Kota Baru Kalimantan Selatan. Pengakuan terhadap Hukum Adat dari suatu daerah yang ada itulah Pemerintah perlu mengambil langkah supaya tidak bertentangan dengan kepentingan negara 
dan bangsa dalam hal ini Hukum Positif. Hal ini adalah wajar sebab Hukum Adat adalah bagian dari hukum yang berlaku dalam Republik Indonesia. ${ }^{1}$

Dapat dimaknai perkawinan tidak hanya melibatkan kedua keluarga tetapi juga lebih kepada melanjutkan keturunan, dimana keturunan bagian yang penting dari gagasan dari melaksanakan perkawinan. Sebelum datangnya agama-agama besar dan resmi yang diakui oleh pemerintah Indonesia, masyarakat adat dayak telah memiliki kepercayaan sendiri yang disebut Kaharingan atau Agama Helo (agama dulu). ${ }^{2}$ Pada saat ini Dayak sudah banyak yang memeluk agama Budha, Kristen, sebagian ada juga yang memeluk agama Islam tetapi masih masih banyak juga masyarakat yang masih menganut kepercayaan Kaharingan.

Dalam perkawinan realitanya, banyak perkawinan yang mengalami suatu permasalahan. Hal ini dikarenakan faktor-faktor seperti tidak ada kecocokan lagi (beda prinsip) antara pasangan suami istri, terjadinya kekerasan dalam rumah tangga dan terjadinya perselingkuhan sehingga mengakibatkan putusnya hubungan perkawinan tersebut atau mengalami perceraian. Menurut pasal 38 Undang-Undang Nomor 1 Tahun 1974 tentang Perkawinan, putusanya perkawinan disebabkan karena 3 (tiga) hal, yaitu : 1. Kematian; 2. Perceraian; 3. Atas keputusan pengadilan.

Dalam masyarakat hukum merupakan satu kesatuan susunan rakyat, ialah masyarakat-masyarakat dusun dan wilayah, maka perkawinan anggautaanggautanya itu adalah suatu peristiwa penting dalam proses masuknya menjadi inti sosial daripada masyarakat itu, itupun bilamana mereka ada kemungkinan masuk. Mengingat hal-hal lainnya mereka lalu mendapat hak-hak dan kewajiban-kewajiban sepenuhnya pula bertanggung jawab mereka atas keselamatan masyarakat dalam arti kata kebendaan dan kerokhanian. ${ }^{3}$

\footnotetext{
${ }^{1}$ Rampay, Darwis Luther. (2003). Perkawinan Menurut Hukum Adat Dayak Ngaju Kalimantan Tengah Ditinjau Dari Undang-Undang Nomor 1 Tahun 1974 Tentang Perkawinan. http://repository.unair.ac.id/35031/12/jiptunair-gdl-s2-2004-rampay2c-1042-perkawinan-th_2903.pdf, h/m.6. Diakses pada tanggal 23/03/2019.

${ }^{2}$ Riwut, Tjilik. (1993). Kalimantan Membangun Alam dan Kebudayaan. Yogyakarta: PT. Tiara Wacana Yogya, hlm. 317.

3 Mr B. Ter Haar Bzn., Terjemahan Poesponoto, Soebakti. (1976). Azas-azas dan Susunan Hukum Adat. Jakarta: PT. Pradnya Paramita, hlm. 187-188.
} 


\section{RUMUSAN MASALAH}

Berdasarkan latar belakang masalah diatas, maka dapat dirumuskan masalah yang akan diteliti sebagai berikut:

1. Bagaimana hukum perkawinan adat pada Masyarakat adat dayak Kabupaten Kotabaru Kalimantan Selatan?

2. Bagaimana hukum perkawinan berdasarkan adat Dayak Kabupaten Kotabaru Kalimantan Selatan ditinjau menurut kajian dan ajaran Asas dan Ilmu Hukum Adat?

\section{METODE PENELITIAN}

Pada hakekatnya, penelitian dalam ilmu hukum berusaha untuk menampilkan perkembangan hukum sesuai dengan kebutuhan kajian ilmu hukum. ${ }^{4}$ Imu hukum dalam praktiknya terus mengalami perkembangan seiring dengan perkembangan perilaku masyarakat. Penelitian yang dilakukan dalam konteks ilmu hukum, maka kajian itu adalah tentang permasalahan pada penerapan hukum, proses hukum, peristiwa hukum, dan ketentuan peraturan hukum itu sendiri baik secara substansi maupun prosedural. ${ }^{5}$ Penelitian hukum merupakan suatu kegiatan ilmiah, yang didasarkan pada metode, sistematika dan pemikiran tertentu, yang bertujuan untuk mempelajari satu atau beberapa gejala hukum tertentu dengan jalan menganalisanya. Selain itu, diadakan pemeriksaan yang mendalam terhadap fakta hukum tersebut, untuk kemudian mengusahakan suatu pemecahan atas permasalahan-permasalahan yang timbul di dalam gejala yang bersangkutan. ${ }^{6}$

Penelitian hukum terhadap gejala hukum dibatasi pada penelitian mengenai norma, kaedah dan asas-asasnya sebagai substansi hukum, penerapan hukum oleh struktur hukum dan mengamati hukum ketika berinteraksi dalam masyarakat sebagai budaya hukum. ${ }^{7}$ Penelitian hukum adalah suatu proses untuk menemukan aturan

${ }^{4}$ Yati Nurhayati, (2013), Perdebatan Antara Metode Normatif Dengan Metode Empirik Dalam Penelitian Ilmu Hukum Ditinjau Dari Karakter, Fungsi, dan Tujuan Ilmu Hukum, A/ Adl: Jurnal Hukum, Vol. 5, No. 10, hlm.15

${ }^{5}$ Yati Nurhayati, Ifrani, \& M. Yasir Said, (2021), Metodologi Normatif dan Empiris Dalam Perspektif Ilmu Hukum, Jurnal Penegakan Hukum Indonesia, Vol. 2, No.1, Tahun 2021, hlm.1-20

${ }^{6}$ Soekanto, Soerjono. (2008). Pengantar Penelitian Hukum, Jakarta: Universitas Indonesia (UI-Press), hlm 43. Lihat pula Muhammad, Abdulkadir. (2004). Hukum dan Penelitian Hukum, Bandung: Citra Aditya Bakti, hlm 32.

${ }^{7}$ Fajar, Mukti dan Yulianto Achmad. (2010). Dualisme Penelitian Hukum Normatif dan Empiris. Yogyakarta: Pustaka Pelajar, hlm 28. 
hukum, prinsip-prinsip hukum, maupun doktrin-doktrin hukum guna menjawab isu hukum yang dihadapi. Penelitian hukum dilakukan untuk menghasilkan argumentasi, teori atau konsep baru sebagai preskripsi dalam menyelesaikan masalah yang dihadapi. Jawaban yang diharapkan di dalam penelitian hukum adalah right, appropriate, inappropriate, atau wrong. Dengan demikian hasil yang diperoleh di dalam penelitian hukum sudah mengandung nilai. ${ }^{8}$

1. Jenis Penelitian: Penelitian ini adalah penelitian socio-legal research. Penelitian ini pertama-tama dilakukan secara empiris (empirical law research) yaitu penelitian hukum positif mengenai perilaku masyarakat dalam berinteraksi. ${ }^{9}$ Penelitian hukum empiris yang dimaksud yakni peneltian terhadap subjek hukum (orang) dengan cara berinteraksi secara langsung di masyarakat sehingga peneltian empiris juga disebut dengan penelitian hukum sosiologis. Adapun hasil dari penelitian empiris tersebut kemudian dikaji secara normative berdasarkan asas-asas hukum dan ajaran ilmu hukum adat berdasarkan doktrin dan teori hukum. Penelitian hukum normatif meletakkan hukum sebagai sebuah bangunan sistem norma. Sistem norma yang dimaksud adalah mengenai asas-asas, norma, kaidah dari peraturan perundangan, putusan pengadilan, perjanjian serta doktrin (ajaran). ${ }^{10}$ Penelitian hukum normatif selalu mengambil isu dari hukum sebagai sistem norma yang digunakan untuk memberikan justifikasi preskriptif tentang suatu peristiwa hukum. Penelitian hukum normatif menjadikan sistem norma sebagai pusat kajiannya. Objek kajian penelitian hukum normatif adalah kaidah atau aturan hukum sebagai suatu bangunan sistem yang terkait dengan peristiwa hukum. Hal ini dilakukan dengan maksud untuk memberikan argumentasi hukum sebagai dasar penentu apakah suatu hlm 35 .

${ }^{8}$ Marzuki, Peter Mahmud. (2009). Penelitian Hukum, Jakarta: Kencana Prenada Media Group, hlm. 95.

${ }^{9}$ Butarbutar, Elisabeth Nurhaini. (2018). Metode Penelitian. Bandung: PT. Refika Aditama,

${ }^{10}$ Fajar, Mukti dan Yulianto Achmad, opcit, hlm 34. Penelitian hukum normatif seringkali hukum dikonsepkan sebagai apa yang tertulis dalam peraturan perundang-undangan (law in books) atau hukum dikonsepkan sebagai kaedah atau norma yang merupakan patokan berperilaku manusia yang dianggap pantas. Bandingkan dengan Amiruddin dan Zainal Asikin. (2006). Pengantar Metode Penelitian Hukum, Jakarta: PT. Raja Grafindo Persada, hlm 118. 
peristiwa sudah benar atau salah serta bagaimana sebaiknya peristiwa itu menurut hukum. ${ }^{11}$

2. Tipe Penelitian: Tipe penelitian adalah tipe penelitian deskriptif yaitu penelitian yang menggambarkan secara jelas, rinci dan sistematis mengenai obyek yang akan diteliti. ${ }^{12}$ Penelitian deskriptif ini dilakukan untuk melihat secara jelas, rinci, sistematis mengenai perkawinan adat pada masyarakat adat dayak Kabupaten Kotabaru Kalimantan Selatan.

3. Sifat Penelitian: Penelitian yang dilakukan adalah bersifat deskriptif, yaitu dengan menggambarkan atau memaparkan dan menjelaskan suatu keadaan yang didasarkan pada gejala-gejala serta fakta-fakta yang diperoleh di lapangan yang kemudian dikaji berdasarkan bahan kepustakaan yang berhubungan dengan permasalah hukum yang diangkat.

4. Jenis Dan Sumber Bahan Hukum: Jenis bahan yang dipergunakan dalam penulisan hukum ini adalah data sekunder yang terdiri atas:

a. Bahan hukum primer adalah bahan yang diperoleh secara langsung melalui penelitian di lapangan yaitu dengan cara wawancara kepada Ketua Adat Dayak Kabupaten Kotabaru Kalimantan Selatan.

b. Bahan hukum sekunder adalah bahan yang diperoleh dari buku-buku, majalah, koran, situs internet, tulisan-tulisan hukum dari ahli hukum yang memberikan penjelasan mengenai bahan hukum primer dan yang berkenaan dengan permasalahan.

c. Bahan hukum tersier adalah bahan yang memberikan informasi, penjelasan, terhadap bahan hukum primer dan skunder yaitu kamus, surat kabar atau jurnal, internet dan informasi lainnya yang mendukung penelitian.

5. Teknik Pengumpulan Bahan Hukum: Teknik pengumpulan bahan hukum, dilakukan melalui studi kepustakaan, yakni mengumpulkan bahan-bahan hukum, baik bahan hukum primer maupun bahan hukum sekunder yang berkaitan dengan hukum perkawinan adat Pada Masyarakat Adat Dayak Kabupaten Kota Baru Kalimantan Selatan. Bahan hukum primer di analis

${ }^{11}$ Fajar ,Mukti dan Yulianto Achmad, ibid., hlm 36.

12 Muhamad, Abdulkadir. (2004). Hukum dan Penelitian Hukum. Bandung: PT. Citra Aditya Bakti, hlm. 115 
dengan langkah-langkah normatif dan dilanjutkan pembahasan desktiptif analisis. Terhadap bahan hukum sekunder dilakukan penelaahan dengan mengacu terhadap pokok pembahasan. Bahan hukum tersier dilakukan penelaahan dengan mengacu kepada petunjuk yang mampu menjelaskan tentang pengertian-pengertian.

Kemudian langkah terakhir setelah melakukan analisa maka dimulailah suatu pembahasan terhadap masalah-masalah yang diangkat yang didasarkan atas analisis dan kajian terhadap bahan-bahan hukum yang telah diperoleh tersebut.

\section{PEMBAHASAN}

\section{Perkawinan Berdasarkan Hukum Adat Suku Dayak Kabupaten Kotabaru Provinsi Kalimantan Selatan}

Berdasarkan data wawancara dengan beberapa responden, ditemukan bahwa ada dua konsep hubungan perkawinan dalam suku adat Dayak, pertama ada perkawinan berdasarkan ikatan suci pernikahan (perkawinan secara sah) dan kedua adalah 'palas' yakni hubungan yang muncul tanpa adanya ikatan pernikahan yang sah dan bahkan bisa dianggap sebagai zinah. Adapun perkawinan berdasarkan ikatan suci pernikahan maka hukumnya tidak ada denda hanya harus memenuhi tradisi hukum adat, sedangkan palas (adanya hubungan zinah) harus diberikan denda dalam bentuk tahil (piring atau mangkok).

Adapun hubungan palas ini adalah hubungan perkawinan akibat hubungan seksual yang dilakukan oleh paman dengan keponakan, kakek dengan cucu, mengambil istri orang, membawa anak orang, dan lain sebagainya. Artinya hubungan ini merupakan hubungan terlarang bahkan dalam hukum adat dayak, akan tetapi hubungan ini bisa dilakukan dengan melakukan 'pembersihan' melalui tahil.

Padahal apabila dilakukan perbandingan dengan hukum perkawinan positif Indonesia. Menurut Undang-Undang Nomor 1 Tahun 1974 tentang Perkawinan menyatakan bahwa perkawinan dilarang antara dua orang yang ${ }^{13}$ :

a. Berhubungan darah dalam garis keturunan lurus kebawah ataupun keatas;

\footnotetext{
${ }^{13}$ Pasal 8, Undang-Undang Republik Indonesia Nomor 1 Tahun 1974 Tentang Perkawinan
} 
b. Berhubungan darah dalam garis keturunan menyamping yaitu antara saudara, antara seorang dengan saudara orang tua dan antara seorang dengan saudara neneknya;

c. Berhubungan semenda, yaitu mertua, anak tiri, menantu dan ibu/bapak tiri;

d. Berhubungan susuan, yaitu orang tua susuan, anak susuan, saudara susuan dan bibi/paman susuan;

e. Berhubungan saudara dengan isteri atau sebagai bibi atau kemenakan dari isteri, dalam hal seorang suami beristri lebih dari seorang;

f. Mempunyai hubungan yang oleh agamanya atau peraturan lain yang berlaku, dilarang kawin.

Selanjutnya merujuk pada Kitab Undang Undang Hukum Perdata (Burgerlijk Wetboek) yang menyatakan bahwa perkawinan dilarang antara mereka, yang mana satu dengan yang lainnya bertalian keluarga dalam garis lurus keatas dan kebawah, baik karena kelahiran yang sah maupun yang tidak sah, atau karena perkawinan; dan dalam garis yang menyimpang, antara saudara laki-laki dan saudara perempuan sah atau tidak sah. ${ }^{14}$

Sehingga dapat dipahami bahwa perkawinan antar saudara yang orang yang seayah dan seibu (sekandung), seayah dan atau seibu. Anggota keluarga dalam garis keturunan kesamping terdiri dari paman bibi beserta keturunannya, baik dari garis pihak ayah maupun garis pihak ibu. Hubungan darah dalam garis keturunan menyamping terdiri dari saudara perempuan ayah, anak perempuan saudara lakilaki, anak perempuan saudara perempuan (kemanakan) ${ }^{15}$ adalah suatu pelanggaran hukum perkawinan nasional.

Sehingga menarik bahwa hubungan-hubungan sebagaimana dijelaskan diatas bisa disahkan dengan dibebankan denda dalam bentuk tahil sebagai bentuk pembersihan. Adapun kalau mempersunting janda tanpa ikatan perkawinan maka tidak berlaku palas. Selanjutnya jumlah denda tahil ini berbeda antar satu hubungan palas dengan hubungan palas lainnya. Misalkan mengawini keponakan berbeda

\footnotetext{
${ }^{14}$ Pasal 30, Kitab Undang Undang Hukum Perdata (Burgerlijk Wetboek).

${ }^{15}$ Ali, Zainudin. (2008). Pelaksanaan Hukum Waris Di Indonesia, Jakarta: Sinar Grafika, hlm. 7.
} 
hukum dan sanksi dendanya dengan mengawini sepupu sekali atau sepupu dua kali. Bahwa mulanya dibebankan 5 tahil, kemudian sealanjutnya dikenal adanya 'sumbang' yakni konsep penyetaraan melalui pembayaran tahil. Hal ini berlaku untuk hubungan yang tidak sepadan contohnya paman dan keponakan maka ditambah 5 tahil untuk menyamakan kedudukan mereka.

Pada prakteknya walaupun dianggap bertentangan dengan hukum perkawinan nasional, tidak dapat dipungkiri bahwa sebagian besar kalangan masyarakat adat Dayak masih berlaku adat dan tata upacara perkawinan ini. Sedangkan UndangUndang No. 1 Tahun 1974 merupakan unifikasi Hukum Perkawinan yang secara aturan umum berlaku untuk perkawinan di Indonesia. ${ }^{16}$

Jika dihubungkan dengan Undang-Undang Nomor 1 Tahun 1974 Tentang Perkawinan yang memuat segala sesuatu berkaitan dengan perkawinan yang berlaku bagi seluruh masyarakat Indonesia, Hal ini tidak sesuai dengan yang dimuat pada Pasal 8b Undang-Undang Nomor 1 Tahun 1974 Tentang Perkawinan. Hal itu disebabkan Undang-undang Perkawinan adalah tetap sebagai dasar hukum yang berlaku secara umum, sementara Hukum Adat hanya sebagai ketentuan khusus yang tidak bertentangan dengan Undang-undang.

Adapun untuk perkawinan berdasarkan ikatan suci pernikahan (bukan palas) maka hanya harus memenuhi hal-hal yang disyaratkan oleh hukum adat Dayak. Bahwa ada konsep yang disebut 'harta kebenaran' (biasanya berjumlah 5 tahil) untuk satu lamaran yang dilakukan oleh laki-laki untuk menandakan bahwa benar-benar ada niat baik untuk menikahi/memperistri mempelai perempuan.

Adapun 5 tahil itu dikumpulkan bisa berjumlah sampai dengan 50 buah piring yang nantinya akan 'dirayang' atau dibagikan satu-satu untuk pejabat-pejabat kampong baik ketua RT, ketua RW, serta Tetua Adat oleh keluarga laki-laki sekaligus sebagai upacara memberitahukan bahwa pernikahan telah terjadi. Sehingga apabila didalam pandangan tetua adat ada hal-hal yang dianggap janggal terhadap jalanya pernikahan tersebut. Maka orang-orang yang diberikan piring tadi mempunyai tanggung jawab untuk memberikan nasehat kepada kedua pasangan suami dan istri. Misalkan si istri membawa laki-laki lain kedalam rumahnya disaat suaminya tidak 274.

${ }^{16}$ Wiranata, I Gede. (2005). Hukum Adat Indonesia, Bandung: PT. Citra Aditya Bakti, hlm. 
ada, maka akan dinasehati bahwa dia sudah memiliki suami untuk dijaga kehormatannya. Selain itu, selama proses peminangan sampai perkawinan apabila ada satu anggota keluarga yang meninggal dunia maka ditambah 2 tahil sebagai "pembasuh banyu mata" atau pembersih air mata diserahkan kepada pihak keluarga yang berduka. Selanjutnya ada hukum 'Pegurau' yang salah satunya memberikan pakaian satu tubuh oleh laki-laki kepada perempuan dari pakaian dalam, pakaian atas sampai, hingga pakaian bawah (seluruh tubuh).

Ada konsep yang menarik dalam hukum perkawinan adat Dayak yang mana mengakui dan menjunjung peran kakek dan nenek dalam membesarkan mempelai perempuan. Pertama adanya hukum 'bebukuan' (yang dapat diartikan sebagai uban). Adapun hubungan dari upacara ini digambarkan bahwa karena cucu nya dipinang maka nenek/kakek tersebut dianggap telah kehilangan cucu karena diambil oleh si laki-laki. Sehingga menurut adat istiadat antara kakek/nenek dengan cucu yang sering minta carikan rambut uban tidak lagi bisa dilakukan karena dia telah bersuami maka untuk menggantikan itu dibayar 2 tahil. Selain itu adapula hukum 'Lapik Luang' yang merupakan tradisi mengganti tapih (sarung). Bahwa secara filosofis kakek/nenek telah merawat dan memelihara cucu (mempelai perempuan) tersebut sampai 'beluang tapih' (robek atau berlubang sarungnya) karena kena kencing cucu waktu bayi dan lain sebagainya. Maka bentuk pemberian dalam upacara ini dilakukan oleh pihak laki-laki yang memberikan sarung atau tapih gendongan baru berjumlah satu buah.

Agar perkawinan dapat diakui oleh hukum adat dayak, maka harus memenuhi tradisi hukum adat, sehingga meskipun sudah ada upacara lamaran dan ditentukan hari perkawianan apabila pihak mempelai tidak bisa memenuhi hukum adat, perkawinan bisa dibatalkan. Sedangkan masakan yang telah dibuat akan dinikmati bersama oleh mayarakat adat.

Oleh sebab itu sebelum melakukan upacara lamaran biasanya keluarga akan mencari silsilah permasalahan antara keluarga mempelai laki-laki dengan keluarga mempelai perempuan yang seharusnya diselesaikan sebelum lamaran. Karena sudah menjadi sifat masyarakat adat Dayak untuk mengingat jikalau ada permasalahan yang pernah terjadi. Contoh permasalahan misalkan dahulu pernah ada sengketa tanah, ada sengketa lokasi pendulangan, permasalahan ternak, atau ada 
perkelahian.

Sehingga dapat gambarkan disaat ada anak laki-laki yang mau mempersunting perempuan yang dicintainya akan tetapi beberapa tahun yang lalu punya masalah dengan salah satu anggota keluarga dari mempelai perempuan. Walaupun seluruh keluarga mempelai perempuan sudah merestui akan tetapi apabila anggota keluarga yang bermasalah tadi tidak datang pada upacara perkawinan, maka harus diadakan kesepakatan perbaikan dan perdamaian. Bahwa anggota keluarga itu harus dicari untuk melakukan perbaikan dengan membayarkan tahil sesuai dengan kesepakatan. Adapun si lelaki harus datang dengan didampingi oleh keluarga atau kerabat untuk meminta maaf dan melakukan perdamaian hasil kesepakatan musyawarah. Jumlah musyawarah tergantung hasil dari kesepakatan, biasanya sampai tiga kali. Musyawarah ini harus menghasilkan kesepakatan. Hal ini diumpamakan sama dengan memperbaiki hubungan keluarga yang sudah retak.

Jika saat lamaran ada permasalahan yang diungkit namun pada kenyataannya telah diselesaikan secara adat, maka tetua adat yang menyelesaikan akan bersaksi bahwa masalah tersebut telah diselesaikan sebelumnya. Karena secara filosofis perkawinan menurut hukum adat dayak, adalah penyatuan ikatan kelurga sehingga apabila ada keluarga yang tidak hadir atau apabila walinya tidak setuju, maka penyatuan itu tidak terpenuhi. Apabila didalam upacara harus ada yang bertanggung jawab atau bertindak sebagai wali, dan jika tidak ada harus dicari sampai ketemu. Maka tahil juga berlaku terhadapnya (piring putih polos yang menandakan pembersihan dan penyucian kesalahan, sehingga tidak boleh bercorak).

Poligami secara adat dayak diperbolehkan namun harus menjalani ketentuan hukum adat. Bahwa yang menjadi permasalahan adalah siapa yang akan dinikahinya. Selain daripada istri harus setuju terlebih dahulu. Sehingga apabila istri tidak setuju berdampak pada kewajiban cerai lebih dahulu. Hal ini untuk menghindari 'palas' karena wanita yang dinikahi akan dianggap mengambil suami orang.

Selanjutnya pada suatu waktu misalkan terjadi perceraian dan kemudian rujuk kembali, maka ada hukum adat yang harus dipatuhi. Akan tetapi misalkan sebelum perceraian sudah diserahkan kepada orang tuanya tetapi orang tuanya tidak setuju, maka perceraian belum sah. Kalaupun masih mau rujuk dengan alasan masih saling mencintai maka orang tua dari laki-laki (suami) akan melakukan musyawarah dengan 
keluarga wanita dengan menghubungi penghulu adat namun tidak perlu dinikahkan lagi asalkan perempuan (istri) tersebut belum dinikahi orang lain lagi. Maka musyawarah dilakukan dengan mendengarkan alasan kenapa pihak ingin bercerai sebelumnya sehingga akan dilakukan kesepakatan dan perjanjian untuk memperbaiki hal-hal yang dirasa kurang dalam perkawinan. Adapun apabila kesepakatan ini dilanggar maka tidak hanya perceraian, namun juga dituntut pidana dengan hukum adat. Perkawinan hukum adat sekarang sudah didaftarkan melalui dukcapil yang datang. Meskipun menganut agama islam atau Kristen maka tetap wajib melalui hukum adat. Kalau untuk kepercayaan kaharingan berdasarkan keterangan dari responden maka biasanya pihak dukcapil datang untuk membantu pendaftaran perkawinan.

\section{Hukum Perkawinan Adat Dayak Kabupaten Kotabaru Dalam Perspekif Asas Hukum dan Ajaran Ilmu Hukum Adat}

Salah satu cara mengkaji suatu hukum adat secara komprehensif adalah dengan mengetahui pandangan-pandangan yang melandasi pemikiran ilmu hukum adat. Sejauh yang bisa ditemukan pada tulisan Ter Haar, Koesnoe dan ilmuwan hukum adat lainnya, pendekatan ilmu hukum adat dilakukan secara positivistik dengan dua pandangan dasar yaitu mengenai susunan/tatanan dari hukum adat dan bagaimana cara bekerjanya. Secara konseptual, pandangan dasar yang pertama berimplikasi pada pandangan dasar kedua. Dalam pandangan dasar yang kedua terdapat penjelasan terkait penalaran mengenai bagaimana hukum adat dioperasikan.

Walaupun terkesan abstrak, hukum adat memiliki unsur yang tersusun dan tertata karena melangsungkan relasi sistematik. Unsur-unsur tersebut terdiri dari yang bersifat umum dan karena itu dapat diberlakukan pada sejumlah tempat atau kasus, dan yang sifatnya konkret karena itu hanya berlaku untuk tempat atau kasus tertentu. Karena masing-masing unsur terhubung dengan logika dan mekanisme sistemik, membuat hukum adat dapat diklasifikasikan sebagai suatu sistem. Bahwa "Sebagai sistem hukum, Hukum Adat memenuhi syarat suatu sistem, ia mempunyai konsepsi-konsepsi dasar, mempunyai unsur-unsur, bagian-bagian, runtut atau konsisten, dan berkelengkapan, yang kesemuanya itu merupakan suatu keseluruhan 
yang terangkal". ${ }^{17}$

Sistem hukum adat memiliki tiga unsur yaitu konsepsi dasar, asas, dan norma. Ketiganya tersusun secara hirarkis yang sekaligus menjelaskan kekuatan validitas. Unsur konsepsi dasar berada pada tingkatan tertinggi pada hirarki tersebut, disusul asas, dan unsur norma pada kedudukan terendah. Konsep dasar dan asas bersifat abstrak dan karena itu dapat berlaku umum. Sedangkan norma, bersifat konkret dan karena itu berlaku hanya pada tempat dan kasus tertentu misalkan secara norma hukum adat denda berupa tahil pada Dayak berbeda sanksi adat pada suku lain, namun konsep dasar adanya sanksi adat merupakan suatu hal yang beraku umum dan abstrak.

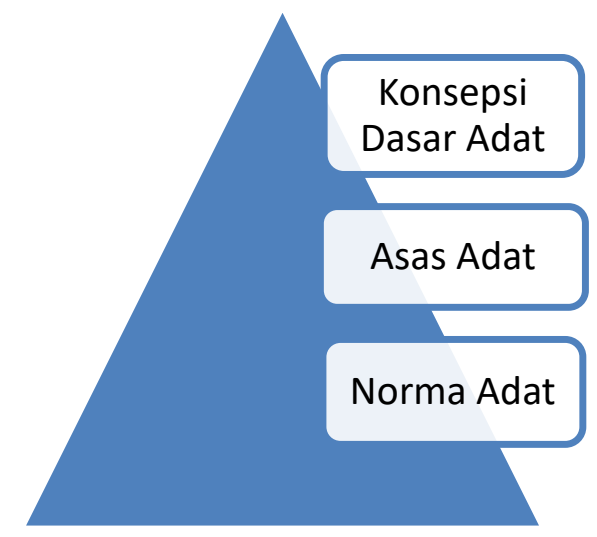

Adapun menurut Koesnoe salah satu unsur formal dari hukum adat adalah kategori-kategori yang mutlak harus ada, secara sistematik dan padu membentuk kerangka yang menjadi sandaran bagi hukum adat bekerja. ${ }^{18}$ Koesnoe menggunakan istilah 'sistem borongan' untuk mencirikan sistem hukum adat. Kedudukan hukum adat sebagai sistem juga dibahas dalam pemikiran yang membahas pembidangan kedalam topik dalam hukum adat. Dari sejak abad kesembilan belas sampai saat ini bahasan hukum adat masing berupa bidang-bidang berikut, yaitu:

a. Susunan persekutuan hukum;

b. Hukum keluarga;

c. Hukum perkawinan;

17 Syamsudin, M. et al.. (1998). Hukum Adat dan Modernisasi Hukum. Yogyakarta: Fakultas Hukum Universitas Islam Indonesia. hlm. 7

${ }^{18}$ Koesnoe, Mohammad. (1998). "Menuju kepada Penyusunan Teori Hukum Adat". Lihat juga Koesnoe, Mohammad. 1979. Catatan-catatan terhadap Hukum Adat dewasa ini, Surabaya: Airlangga University Press, hlm. 55. 
d. Hukum waris;

e. Hukum tanah dan air;

f. Hukum perutangan; dan

g. Delik adat

Kategori atau bidang bahasan Susunan Persekutuan Kukum ditaruh di awal untuk menjadikannya sebagai landasan enam kategori berikutnya, terutama yang kedua sampai keempat. Susunan Persekutuan Hukum yang dapat didasarkan pada ikatan teritori, keturunan (genealogis), atau campuran keduanya, berpengaruh pada hukum keluarga, perkawinan, dan waris. Status hak dan kewajiban seseorang, bentuk-bentuk perkawinan, dan pembagian warisan, ditentukan oleh ikatan persekutuan. Selanjutnya Van Vollenhoven menjadikan ketujuh kategori atau bidang bahasan diatas sebagai ukuran untuk membagi Indonesia kedalam 19 lingkaran hukum adat (adatrechtskring). Setiap lingkaran hukum adat memiliki ketujuh kategori tersebut. Pembagian kedalam lingkaran hukum adat sebenarnya merupakan bagian dari proses menemukan unsur-unsur umum dalam hukum adat. Ketujuh kategori tersebut adalah hal-hal yang dianggap ada pada semua persekutuan hukum adat, terlepas dari masih adanya suatu ke khas an yang hanya dijumpai pada satu atau beberapa persekutuan. Unsur-unsur umum lewat Dalam masing-masing kategori hukum adat tersebut selanjutnya berkembang konsepsi dasar dan asas.

Lebih lanjut menurut Koesnoe, hukum adat bekerja dengan asas-asas pokok. Asas-asas inilah yang bersifat umum dan tetap.Koesnoe menjelaskan bahwa asasasas dalam hukum adat yaitu pantas, patut, rukun, dan laras, sesuai dengan keadaan zaman, dan rasa keadilan. Asas-asas tersebut digunakan sebagai pertimbangan untuk memutuskan apakah terjadi atau tidak terjadi pelanggaran adat.

Substansi asas rukun adalah orientasi hidup bersama dalam satu lingkungan dengan tujuan mencapai hidup aman, tentram dan sejahtera. Orientasi ini didasarkan pada alasan bahwa setiap orang memerlukan satu sama lain. Satu modal besar untuk memiliki orintasi hidup yang seperti itu adalah menjauhkan pergaulan sosial dari pertimbangan untung rugi. Sebaliknya, harus dikembangkan perasaan saling mengerti, menerima, dan memaafkan kesalahan atau kekurangan orang lain. Asas rukun merupakan bagian dari ajaran berkehendak dan berkarya bersama. Intisari dari ajaran berkendak bersama adalah musyawarah untuk mufakat, 
sedangkan ajaran berkarya bersama adalah gotong royong atau tolong menolong. Sedangkan Asas patut berkaitan dengan kesusilaan, mengenai perbuatan baik dan buruk. Untuk bisa mengenali perbuatan baik atau buruk, digunakan akal atau pikiran sehat (akal budi). Karena menyangkut kesusilaan, asas ini mempertimbangkan kualitas pihakpihak yang terlibat dengan memperhatikan kehormatan atau harga diri yang bermuara pada keluhuran sebagai manusia. Salah satu cara untuk menjaga harga diri adalah dengan mencegah seseorang dipojokan oleh rasa malu. Keragaman penerapan asas ini salah satunya disebabkan oleh perbedaan penekanan pada kesusilaan dan akal sehat. Penekanan pada akal sehat memunculkan suatu istilah yang lebih tepat, yaitu layak. Asas yang terakhir yaitu laras menunjuk pada proses menghasilkan putusan yang secara optimal bisa memenuhi rasa estetik para pihak dan masyarakat. Karena itu ajaran laras menunjuk pada situasi setelah putusan diambil dengan memperhatikan penerimaan para pihak dan masyarakat. Putusan yang mengandung ajaran laras adalah yang tidak menyebabkan perselisihan lanjutan karena para pihak atau masyarakat tidak memandang putusan tersebut sebagai jawaban. Agar bisa menjawab keinginan tersebut, keputusan sebaiknya diambil dengan menggunakan kebijaksanaan yaitu belajar dari pengalaman-pengalaman masa sebelumnya. ${ }^{19}$

Sehingga apabila merujuk pada hukum perkawinan adat Dayak Dapat ditarik penerapan asas-asas ini pada norma-norma adat antara lain:

a. Asas Rukun: Bahwa sebelum melakukan upacara lamaran biasanya keluarga akan mencari silsilah permasalahan antara keluarga mempelai laki-laki dengan keluarga mempelai perempuan yang seharusnya diselesaikan sebelum lamaran. Apabila anggota keluarga yang bermasalah tadi tidak datang pada upacara perkawinan, maka harus diadakan kesepakatan perbaikan dan perdamaian dengan membayarkan tahil sesuai dengan kesepakatan. Adapun dilakukan upacara saling meminta maaf, memaafkan dan melakukan perdamaian hasil kesepakatan musyawarah. Jumlah musyawarah tergantung hasil dari kesepakatan, biasanya sampai

${ }^{19}$ Koesnoe, Mohammad. (1974). "Tentang Tiga Asas-Asas Kerja Untuk Menghadapi PerkaraPerkara Hukum Adat Indonesia," dalam Lima Puluh Tahun Pendidikan Hukum Di Indonesia, Jakarta: Fakultas Hukum Universitas Indonesia, hlm. 237. 
tiga kali sampai menghasilkan kesepakatan. Selanjutnya, Poligami secara adat dayak diperbolehkan namun istri harus setuju terlebih dahulu. Selanjutnya pada suatu waktu misalkan terjadi perceraian dan kemudian rujuk kembali, maka dilakukan musyawarah dengan menghubungi penghulu adat. Musyawarah dilakukan dengan mendengarkan alasan kenapa pihak ingin bercerai sebelumnya sehingga akan dilakukan kesepakatan dan perjanjian untuk memperbaiki hal-hal yang dirasa kurang dalam perkawinan.

b. Asas Patut: Adanya palas harus diberikan denda dalam bentuk tahil (piring atau mangkok). Palas sebagai hubungan terlarang dibebankan denda dalam bentuk tahil sebagai bentuk pembersihan. Selanjutnya dikenal adanya 'sumbang' yakni konsep penyetaraan melalui pembayaran tahil yang berlaku untuk hubungan yang tidak sepadan/setara. ada konsep yang disebut 'harta kebenaran' untuk satu lamaran yang dilakukan oleh laki-laki untuk menandakan bahwa benar-benar ada niat baik untuk menikahi/memperistri mempelai perempuan. Adanya asas tanggungjawab oleh penerima tetua adat yang 'dirayang' untuk membantu kelangsungan ikatan perkawinan. Kemudian adanya hukum adat "pembasuh banyu mata" melalui tambahan 2 tahil kepada keluarga yang ditinggalkan/berduka. Adanya 'Pegurau' untuk memberikan pakaian satu tubuh oleh mempelai laki-laki kepada mempelai perempuan. Adanya hukum 'bebukuan' yang dibayar sejumlah 2 tahil. Selain itu ada 'Lapik Luang' yang merupakan tradisi mengganti tapih dengan memberikan sarung atau tapih gendongan baru berjumlah satu buah.

c. Asas Laras: Jika saat lamaran ada permasalahan yang diungkit namun pada kenyataannya telah diselesaikan secara adat, maka tetua adat yang menyelesaikan akan bersaksi bahwa masalah tersebut telah diselesaikan sebelumnya.

Selanjutnya apabila merujuk pada pandangan Frederiech Karl Von Savigny yang menyatakan bahwa hukum merupakan pencerminan dari jiwa rakyat, yang oleh muridnya G. Puchta dinamainya volgeist, hukum tumbuh dan kuat bersama-sama dengan pertumbuhan rakyat dan dari kekuatan rakyat dan pada akhirnya dia mati 
jika bangsa itu hilang kebangsaannya. Maka hukum adat dayak kabupaten kotabaru adalah hukum non statutoir yang sebagian besar adalah hukum kebiasaan. Sehingga dapat ditarik bahwa hukum perkawinan adat dayak kotabaru adalah suatu hukum yang hidup diwilayah masyarakat adat dayak, karena ia menjelmakan perasaan hukum dari lokal. Sesuai fitrahnya, hukum adat terus menerus dalam keadaan tumbuh dan berkembang seperti kehidupan masyarakat itu sendiri. ${ }^{20}$

\section{PENUTUP}

Ada dua konsep hubungan perkawinan dalam suku adat Dayak, pertama ada perkawinan berdasarkan ikatan suci pernikahan (perkawinan secara sah) dan kedua adalah 'palas' yakni hubungan yang muncul tanpa adanya ikatan pernikahan yang sah dan bahkan bisa dianggap sebagai zinah. Untuk perkawinan berdasarkan ikatan suci pernikahan (bukan palas) maka hanya harus memenuhi hal-hal yang disyaratkan oleh hukum adat Dayak. Bahwa ada konsep yang disebut 'harta kebenaran' (biasanya berjumlah 5 tahil) untuk satu lamaran yang dilakukan oleh laki-laki untuk menandakan bahwa benar-benar ada niat baik untuk menikahi/memperistri mempelai perempuan. untuk perkawinan berdasarkan ikatan suci pernikahan (bukan palas) maka hanya harus memenuhi hal-hal yang disyaratkan oleh hukum adat Dayak. Bahwa ada konsep yang disebut 'harta kebenaran' (biasanya berjumlah 5 tahil) untuk satu lamaran yang dilakukan oleh laki-laki untuk menandakan bahwa benar-benar ada niat baik untuk menikahi/memperistri mempelai perempuan

Sistem hukum adat memiliki tiga unsur yaitu konsepsi dasar, asas, dan norma. Ketiganya tersusun secara hirarkis yang sekaligus menjelaskan kekuatan validitas. Unsur konsepsi dasar berada pada tingkatan tertinggi pada hirarki tersebut, disusul asas, dan unsur norma pada kedudukan terendah. Konsep dasar dan asas bersifat abstrak dan karena itu dapat berlaku umum. Sedangkan norma, bersifat konkret dan karena itu berlaku hanya pada tempat dan kasus tertentu misalkan secara norma hukum adat denda berupa tahil pada Dayak berbeda sanksi adat pada suku lain, namun konsep dasar adanya sanksi adat merupakan suatu hal yang beraku umum dan abstrak.

${ }^{20}$ Murdan. (2016). "Pluralisme Hukum (Adat Dan Islam) Di Indonesia", Jurnal Kajian Hukum Islam, Program Pasca Sarjana, UIN Sunan Kalijaga Yogyakarta, Vol. 1, No. 1, Juni, hlm. 57. 


\section{DAFTAR PUSTAKA}

Ali, Zainudin. (2008). Pelaksanaan Hukum Waris Di Indonesia, Jakarta: Sinar Grafika.

Amiruddin dan Zainal Asikin. (2006). Pengantar Metode Penelitian Hukum, Jakarta: PT. Raja Grafindo Persada.

Butarbutar, Elisabeth Nurhaini. (2018). Metode Penelitian. Bandung: PT. Refika Aditama.

B. Ter Haar Bzn., Terjemahan Poesponoto, Soebakti. (1976). Azas-azas dan Susunan Hukum Adat. Jakarta: PT. Pradnya Paramita.

Fajar, Mukti dan Yulianto Achmad. (2010). Dualisme Penelitian Hukum Normatif dan Empiris. Yogyakarta: Pustaka Pelajar.

Koesnoe, Mohammad. (1979). Catatan-catatan terhadap Hukum Adat dewasa ini, Surabaya: Airlangga University Press.

. (1974). "Tentang Tiga Asas-Asas Kerja Untuk Menghadapi

Perkara-Perkara Hukum Adat Indonesia," dalam Lima Puluh Tahun Pendidikan Hukum Di Indonesia, Jakarta: Fakultas Hukum Universitas Indonesia.

Murdan. (2016). "Pluralisme Hukum (Adat Dan Islam) Di Indonesia", Jurnal Kajian Hukum Islam, Program Pasca Sarjana, UIN Sunan Kalijaga Yogyakarta, Vol. 1, No. 1, Juni.

Marzuki, Peter Mahmud. (2009). Penelitian Hukum, Jakarta: Kencana Prenada Media Group.

Muhamad, Abdulkadir. (2004). Hukum dan Penelitian Hukum. Bandung: PT. Citra Aditya Bakti.

Rampay, Darwis Luther. (2003). Perkawinan Menurut Hukum Adat Dayak Ngaju Kalimantan Tengah Ditinjau Dari Undang-Undang Nomor 1 Tahun 1974 Tentang Perkawinan. http://repository.unair.ac.id/35031/12/jiptunair-gdls2-2004-rampay2c-1042-perkawinan-th_29-03.pdf, h/m.6. Diakses pada tanggal 23/03/2019.

Riwut, Tjilik. (1993). Kalimantan Membangun Alam dan Kebudayaan. Yogyakarta: PT. Tiara Wacana Yogya.

Soekanto, Soerjono. (2008). Pengantar Penelitian Hukum, Jakarta: Universitas Indonesia (UI-Press), hlm 43. Lihat pula Muhammad, Abdulkadir. (2004). Hukum dan Penelitian Hukum, Bandung: Citra Aditya Bakti. 
Syamsudin, M. et al.. (1998). Hukum Adat dan Modernisasi Hukum. Yogyakarta: Fakultas Hukum Universitas Islam Indonesia.

Wiranata, I Gede. (2005). Hukum Adat Indonesia, Bandung: PT. Citra Aditya Bakti.

Yati Nurhayati, (2013), Perdebatan Antara Metode Normatif Dengan Metode Empirik Dalam Penelitian Ilmu Hukum Ditinjau Dari Karakter, Fungsi, dan Tujuan Ilmu Hukum, A/ Adl: Jurnal Hukum, Vol. 5, No. 10.

Yati Nurhayati, Ifrani, \& M. Yasir Said, (2021), Metodologi Normatif dan Empiris Dalam Perspektif Ilmu Hukum, Jurnal Penegakan Hukum Indonesia, Vol. 2, No.1, Tahun 2021. 